\title{
ANALISIS PERBANDINGAN ARUS JENUH PADA PENDEKAT SIMPANG TERLINDUNG DAN TERLAWAN DENGAN METODE MKJI DAN METODE TIME SLICE (STUDI KASUS: SIMPANG SUBITA DAN SIMPANG WARIBANG)
}

\author{
I Made Kariyana ${ }^{1)}$, Gede Sumarda ${ }^{1)}$, dan I Gede Aryanta Putra ${ }^{1)}$ \\ 1) Program Studi Teknik Sipil, Universitas Ngurah Rai, Denpasar, Bali \\ madekariyana@gmail.com
}

\begin{abstract}
As many as 33\% of vehicle ownership in Bali Province in 2019 was in Denpasar City, coupled with the passing of vehicles from outside the city to work and recreation to burden the road network in Denpasar City. This causes problems in the transportation system that affects the performance of the road network, especially the performance of signalized intersection in Denpasar City. The performance of the signalized intersection is affected by the capacity of the approach where one of the factors that affect it is saturation flow. This study aims to find out the comparison of saturation flow in protected and opposed approach between the IHCM and Time Slice Method. The saturation flow result in the protected approach in Simpang Subita based on IHCM is 3,629 pcu/green hours greater than $71.18 \%$ compared to the Time Slice Method which is 2,120 pcu/green hours, while the saturation flow result in the opposed approach in Simpang Waribang based on IHCM is 1,857 pcu/green hour smaller than $37.49 \%$ compared to the Time Slice Method which is 2,971 pcu/green hour.
\end{abstract}

Keywords: saturation flow, protected and opposed approach, IHCM, time slice

\begin{abstract}
ABSTRAK
Sebanyak 33\% kepemilikan kendaraan di Provinsi Bali pada tahun 2019 berada di Kota Denpasar, ditambah dengan melintasnya kendaraan dari luar kota untuk bekerja maupun berekreasi ikut membebani jaringan jalan di Kota Denpasar. Hal tersebut menimbulkan permasalahan pada sistem transportasi yaitu mempengaruhi kinerja jaringan jalan khususnya kinerja simpang bersinyal di Kota Denpasar. Kinerja simpang bersinyal dipengaruhi oleh kapasitas dari pendekatnya dimana salah satu faktor yang mempengaruhinya adalah arus jenuh. Penelitian ini bertujuan untuk mengetahui perbandingan arus jenuh pada pendekat terlindung dan terlawan antara Metode MKJI dengan Time Slice. Hasil arus jenuh pada pendekat terlindung di Simpang Subita berdasarkan MKJI adalah 3,629 smp/jam hijau lebih besar 71.18\% dibandingkan dengan Metode Time Slice yaitu 2,120 smp/jam hijau, sedangkan hasil arus jenuh pada pendekat terlawan di Simpang Waribang berdasarkan MKJI adalah 1,857 smp/jam hijau lebih kecil $37.49 \%$ dibandingkan dengan Metode Time Slice yaitu 2,971 smp/jam hijau.
\end{abstract}

Kata kunci: arus jenuh, pendekat terlindung dan terlawan, MKJI, time slice 


\section{PENDAHULUAN}

Denpasar yang merupakan ibu Kota provinsi Bali adalah pusat dari kegiatan masyarakat seperti kegiatan pada bidang pemerintahan, pendidikan, ekonomi, maupun hiburan (Kariyana et al., 2019). Jumlah kendaraan di provinsi Bali pada tahun 2019 adalah sebanyak 4,352,592 kendaraan sedangkan jumlah kendaraan di Kota Denpasar sebanyak 1,420,997 kendaraan (Anonim, 2020). Hal tersebut menunjukkan bahwa kepemilikan kendaraan di Kota Denpasar adalah sebesar 33\% dari total kendaraan yang ada di provinsi Bali, belum lagi ditambah dengan kendaraan logistik dan angkutan umum antar Kota maupun antar provinsi serta kendaraan umum yang melintasi jaringan jalan di Kota Denpasar untuk bekerja, berekreasi ataupun hanya melewati Kota Denpasar ke kabupaten lainnya. Hal ini berdampak pada timbulnya permasalahan pada sistem transportasi di Kota Denpasar yang mempengaruhi kinerja jaringan jalan yaitu kinerja dari simpang bersinyal.

Pada Manual Kapasitas Jalan Indonesia (MKJI) 1997 disebutkan bahwa simpang bersinyal adalah suatu persimpangan yang terdiri dari beberapa pendekat dan dilengkapi Alat Pemberi Isyarat Lampu Lalu Lintas (APILL).
Terdapat dua tipe pendekat pada simpang bersinyal yaitu pendekat terlindung (P/Protected) dan pendekat terlawan (O/Opposed), dimana pendekat terlindung merupakan pendekat dengan keberangkatan tanpa terjadinya konflik sedangkan pendekat terlawan merupakan pendekat dengan keberangkatan yang mengalami konflik. Salah satu hal yang mempengaruhi kinerja dari suatu simpang bersinyal adalah kapasitas dan arus lalu lintas dari masing-masing pendekatnya (Lubis, 2017). Terdapat beberapa faktor yang mempengaruhi kapasitas dari pendekat pada simpang bersinyal salah satunya adalah arus jenuh. Arus jenuh adalah volume maksimum kendaraan yang dapat melewati garis henti pada jalur pendekat saat lampu hijau (Balaka \& Yudistira, 2018). Ketika jumlah antrian yang ada melebihi kapasitas arus jenuh maka kinerja simpang bersinyal menjadi menurun (Bowoputro et al., 2014). Penentuan arus jenuh pada pendekat di simpang bersinyal pada umumnya menggunakan ketentuan yang terdapat pada MKJI.

Berdasarkan penelitian terdahulu tentang arus jenuh pada pendekat simpang bersinyal di Kota Denpasar oleh Kariyana et al. (2019) pada Pendekat Yos Sudarso di Simpang Sudirman-Yos Sudarso dengan 
lebar efektif pendekat 6 meter diperoleh arus jenuh berdasarkan MKJI adalah sebesar 2,100 smp/jam lebih kecil dibandingkan arus jenuh menggunakan Metode Time Slice untuk slice 3 detik yaitu 2,350 smp/jam dan untuk 6 detik adalah 2,398 smp/jam, sehingga perlu dilakukan penyesuaian terhadap ketentuan yang terdapat pada MKJI sesuai dengan kondisi lalu lintas terkini. Sedangkan penelitian lainnya oleh Negara et al. (2019) pada Pendekat Gatot Subroto di Simpang Gatot Subroto-Kebo Iwa dengan lebar efektif pendekat 7.5 meter diperoleh arus jenuh yang relatif sama antara MKJI dan Metode Time Slice dimana nilai arus jenuh MKJI sebesar 3,855 smp/jam dan Metode Time Slice sebesar 3,856 smp/jam, sehingga Metode MKJI masih valid diaplikasikan untuk analisis perancangan, perencanaan dan operasional simpang bersinyal dengan kondisi geometrik, lalu lintas dan lingkungan tertentu. Kedua penelitian tersebut dilakukan pada pendekat tipe terlindung tetapi menghasilkan kesimpulan yang berbeda terhadap penggunaan MKJI dalam perhitungan arus jenuh. Oleh sebab itu, maka peneliti ingin mengetahui lebih lanjut tentang perbedaan nilai arus jenuh pada pendekat tipe terlindung maupun terlawan antara Metode MKJI dan Metode Time Slice.

\section{KAJIAN PUSTAKA}

Arus lalu lintas berinteraksi dengan sistem jaringan transportasi khususnya jalan di persimpangan. Persimpangan merupakan faktor terpenting dalam menentukan kapasitas dan waktu tempuh pada suatu jaringan jalan, terutama di daerah perkotaan (Susilo dan Solihin, 2011).

\subsection{Arus Lalu Lintas}

Arus lalu lintas sering dianggap sama dengan volume ataupun aliran lalu lintas karena mengandung pengertian jumlah kendaraan yang terdapat dalam ruang yang diukur pada interval waktu tertentu (Subandi dan Gunawan, 2017). Arus lalu lintas (Q) untuk setiap pergerakan kendaraan yaitu lurus (QsT), belok kanan (QRT) dan belok kiri (QLT) pada masing-masing tipe pendekat dirubah dari kendaraan per jam menjadi satuan mobil penumpang (smp) per jam dengan ekivalen mobil penumpang (emp) (Anonim, 1997), dimana besaran nilai emp dapat dilihat pada Tabel 1.

Tabel 1. Nilai emp pada Simpang Bersinyal

\begin{tabular}{ccc}
\hline Jenis Kendaraan & \multicolumn{2}{c}{ emp } \\
\hline $\begin{array}{c}\text { Kendaraan Ringan } \\
(\mathrm{LV})\end{array}$ & 1.0 & 1.0 \\
$\begin{array}{c}\text { Kendaraan Berat } \\
\quad(\mathrm{HV})\end{array}$ & 1.3 & 1.3 \\
$\begin{array}{c}\text { Sepeda Motor } \\
\text { (MC) }\end{array}$ & 0.2 & 0.4 \\
\hline Sumber: Anonim, 1997 & &
\end{tabular}

Sumber: Anonim, 1997 
Dalam MKJI perhitungan arus lalu lintas kendaraan bermotor dilakukan setiap satu jam pada satu atau beberapa periode, berdasarkan kondisi arus lalu lintas pada jam puncak pagi, siang dan sore seperti yang dinyatakan dalam persamaan 1 :

$$
\mathrm{Q}=\mathrm{Q}_{\mathrm{LV}}+\mathrm{Q}_{\mathrm{HV}} \cdot \mathrm{emp}_{\mathrm{HV}}+\mathrm{Q}_{\mathrm{MC}} \cdot \mathrm{emp}_{\mathrm{MC}}
$$

\subsection{Arus Jenuh}

Arus maksimum yang berhasil dilewatkan pada suatu ruas jalan disebut dengan kapasitas ruas jalan. Arus maksimum yang dapat melewati suatu titik pada simpang bersinyal biasa disebut dengan arus jenuh (Tamin, 2000). Berdasarkan Pedoman Kapasitas Jalan Indonesia (PKJI) tahun 2014, kapasitas pendekat pada simpang bersinyal dipengaruhi oleh beberapa faktor, yaitu nilai arus jenuh (S), waktu hijau efektif (g) dan waktu siklus (c) seperti yang dinyatakan dalam persamaan 2 :

$$
\mathrm{C}=\mathrm{S} \times \mathrm{g} / \mathrm{c}
$$

\section{Dalam Transportation Research} Board (2000) disebutkan bahwa arus jenuh merupakan arus maksimal yang bisa dilewatkan pendekat simpang bersinyal saat lampu menyala hijau. Permulaan arus berangkat dapat menyebabkan 'Kehilangan awal' dari waktu hijau efektif, sedangkan arus yang berangkat setelah akhir dari waktu hijau dapat menyebabkan suatu
'Tambahan akhir' dari waktu hijau efektif. Pada saat lampu merah arus masih sangat besar itu disebabkan karena saat lampu merah menyala masih ada waktu tambahan akhir untuk meghabiskan semua arus lalu lintas di mulut simpang, dan pada saat itu lampu merah menyala di seluruh pendekat. Hal tersebut ditunjukkan pada Gambar 1.

\subsubsection{Metode MKJI 1997}

Arus jenuh (S) merupakan hasil perkalian dari arus jenuh dasar $\left(\mathrm{S}_{0}\right)$ dengan faktor penyesuaian $(\mathrm{F})$ sebagai akibat dari penyimpangan kondisi ideal yang telah ditetapkan sebelumnya. Arus jenuh dasar dihitung berdasarkan konsep lebar efektif pendekat pada simpang bersinyal (lubis dan surbakti, 2017) yaitu besarnya keberangkatan antrian pada pendekat selama kondisi ideal (smp/jam hijau) yang dinyatakan dalam persamaan 3 . Sedangkan faktor penyesuaian dilakukan menurut ukuran kota (CS), Hambatan Samping $(\mathrm{SF})$, kelandaian $(\mathrm{G})$, Parkir $(\mathrm{P})$, gerakan membelok (RT, LT) seperti yang dinyatakan dalam persamaan 4 .

$$
\begin{aligned}
& \mathrm{S}_{0}=600 \times \mathrm{W}_{\mathrm{e}} \ldots \ldots \ldots \ldots \ldots \ldots \ldots \ldots \ldots \ldots \ldots \ldots \\
& \mathrm{S}=\mathrm{S}_{0} \times \mathrm{F}_{\mathrm{CS}} \times \mathrm{F}_{\mathrm{SF}} \times \mathrm{F}_{\mathrm{G}} \times \mathrm{F}_{\mathrm{P}} \times \mathrm{F}_{\mathrm{RT}} \times \mathrm{F}_{\mathrm{LT}}
\end{aligned}
$$

\subsubsection{Metode time slice}

Metode pengukuran arus jenuh yang dilakukan berdasarkan data yang diperoleh langsung di lapangan dikenal dengan metode time slice. Arus jenuh dinyatakan 
dalan satuan unit kendaraan per-jam (kendaraan/jam waktu hijau atau smp/jam waktu hijau ditentukan dengan mengamati saat kendaraan mulai bergerak saat awal waktu hijau (dalam antrian) menggunakan periode hijau yang lebih kecil (Nguyen dan Montgomery, 2007). Dasar metode ini adalah membagi setiap periode hijau pada kondisi jenuh dan selanjutnya:

1. Merata-ratakan arus lalu lintas dalam kondisi jenuh yang bebas dari pengaruh waktu hilang untuk memperoleh nilai arus jenuh.

2. Menggunakan arus lalu lintas pada slice yang terpengaruh oleh kehilangan awal dan waktu kuning untuk memperoleh waktu hilang.
Periode hijau yang dimaksud adalah penjumlahan dari tampilan waktu hijau dan waktu kuning. Arus jenuh adalah rata-rata arus pada kondisi jenuh selama waktu hijau, tanpa menyertakan nilai arus pada slice awal dan slice akhir (Fadli dan Elkhasnet, 2012) seperti yang terlihat pada Gambar 2.

Rumus yang digunakan dalam perhitungan arus jenuh dengan Metode Time Slice menggunakan persamaan 5 (Panjaitan, et al., 2018).

$$
\mathrm{S}=Q \times \frac{3600}{t}
$$

dimana:

$\mathrm{S}$ : Arus Jenuh (smp/jam)

Q : Arus Lalu lintas (smp/t detik)

$\mathrm{T}$ : Waktu Irisan/Slice (detik)

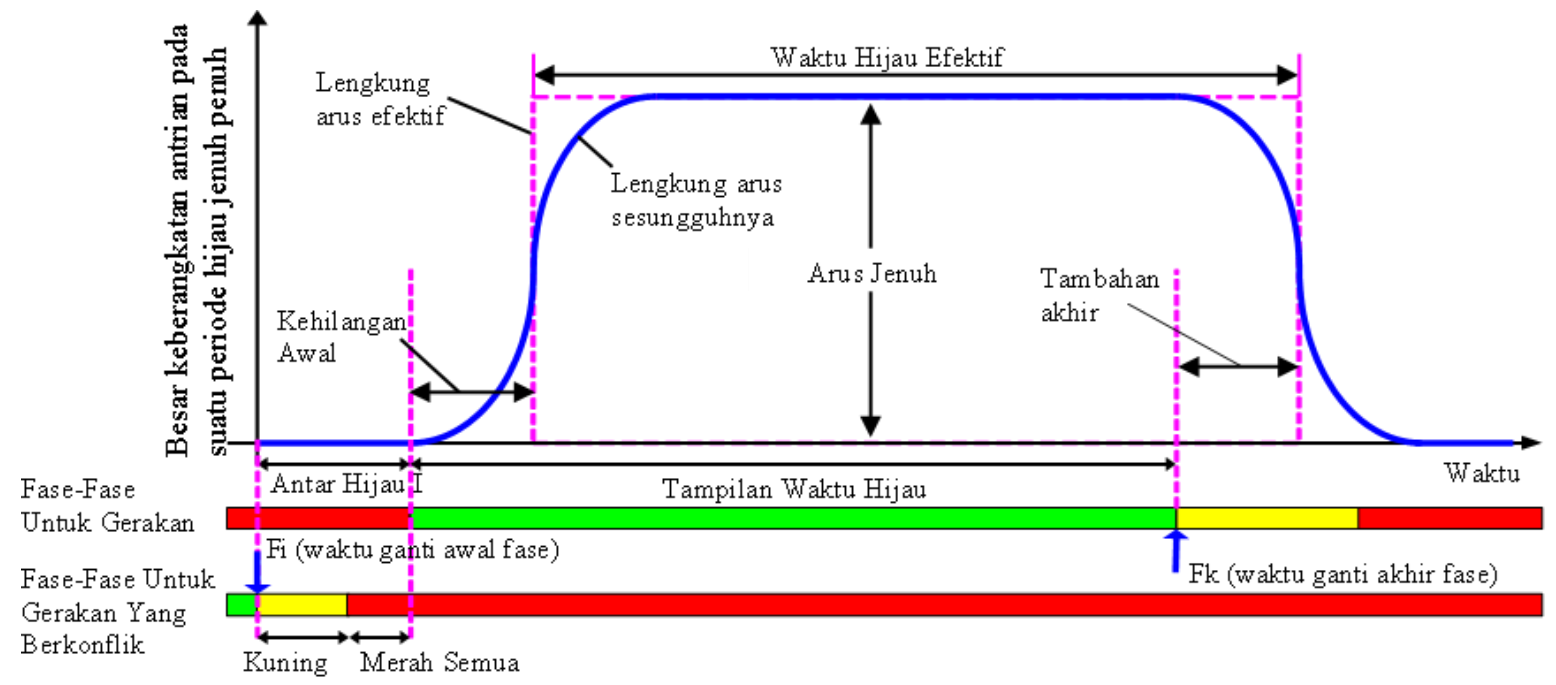

Gambar 1. Model Dasar untuk Arus Jenuh

(Sumber: Anonim, 1997) 


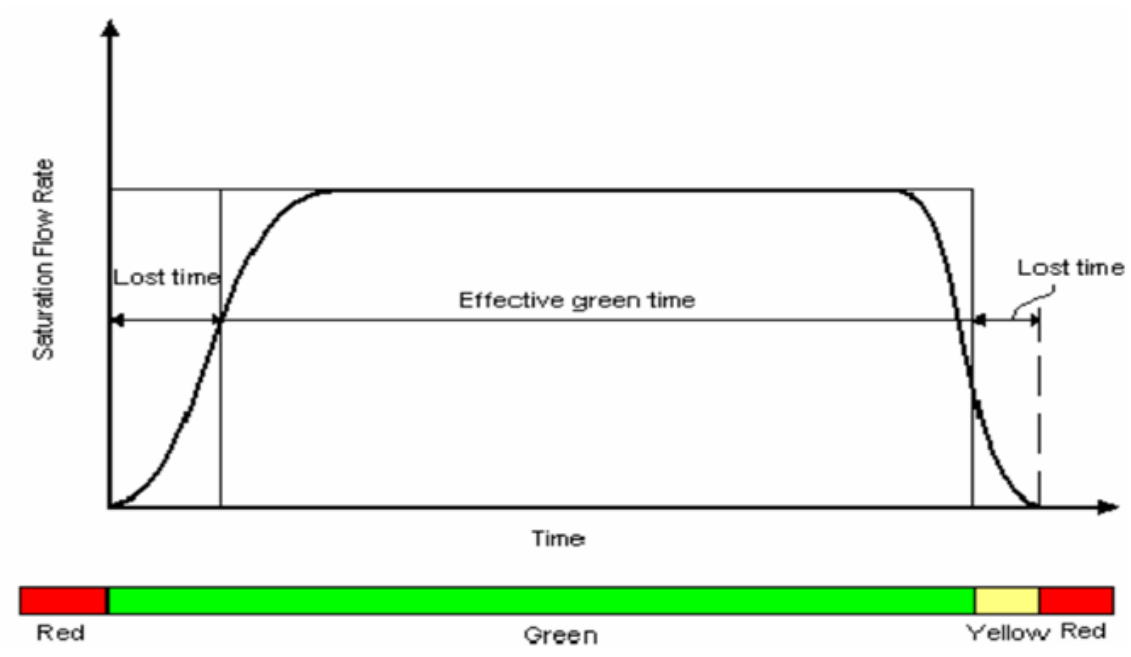

Gambar 2. Pengukuran arus jenuh dengan Metode Time Slice

(Sumber: Nguyen, 2016)

\section{METODE PENELITIAN}

\subsection{Lokasi Penelitian}

Berdasarkan pengamatan awal pada beberapa simpang di Kota Denpasar maka ditentukan lokasi studi penelitian untuk pendekat terlindung adalah pendekat barat di Simpang Subita dan untuk pendekat terlawan adalah pendekat barat di Simpang Waribang. Kedua simpang dipilih karena merupakan salah satu akses menuju kawasan tujuan pergerakan sehingga memiliki volume lalu lintas yang cukup padat dan sering terjadi antrian kendaraan saat memasuki simpang pada jam-jam sibuk. Selain itu kedua simpang belum pernah digunakan sebagai tinjauan untuk studi penelitian terkait arus jenuh. Peta Lokasi kedua simpang dapat dilihat pada Gambar 3 dan 4.

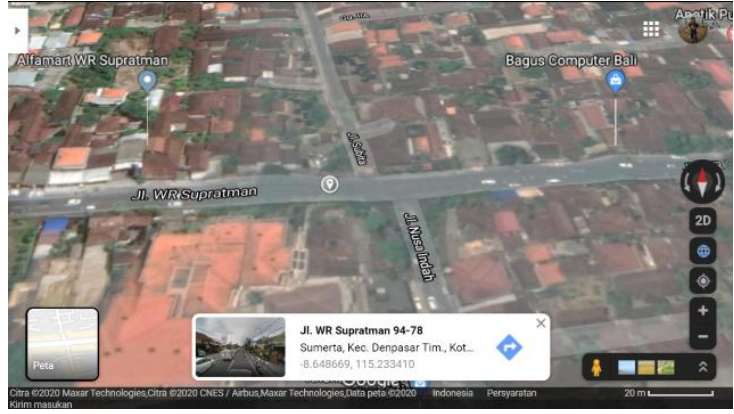

Gambar 3. Peta Lokasi Simpang Subita

(Sumber: Google Map, 2020)

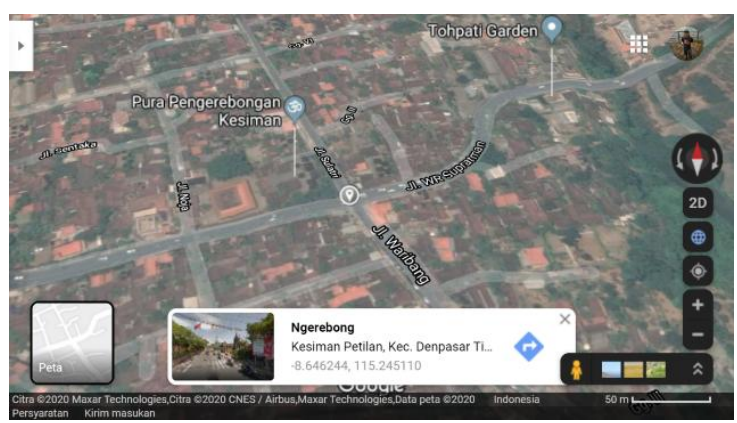

Gambar 4. Peta Lokasi Simpang Waribang (Sumber: Google Map, 2020)

\subsection{Tahapan Penelitian}

Penelitian dilakukan menggunakan metode kuantitatif dimana data penelitiannya diperoleh dengan survei langsung di lapangan seperti geometrik simpang, fase dan waktu sinyal lalu-lintas 
serta data dari instansi terkait berupa jumlah penduduk dan rekaman Area Traffic Control System (ATCS) yang selanjutnya dianalisis sesuai dengan ketentuan yang terdapat pada MKJI maupun dengan Metode Time Slice. Tahapan penelitian dapat dilihat pada Gambar 5.

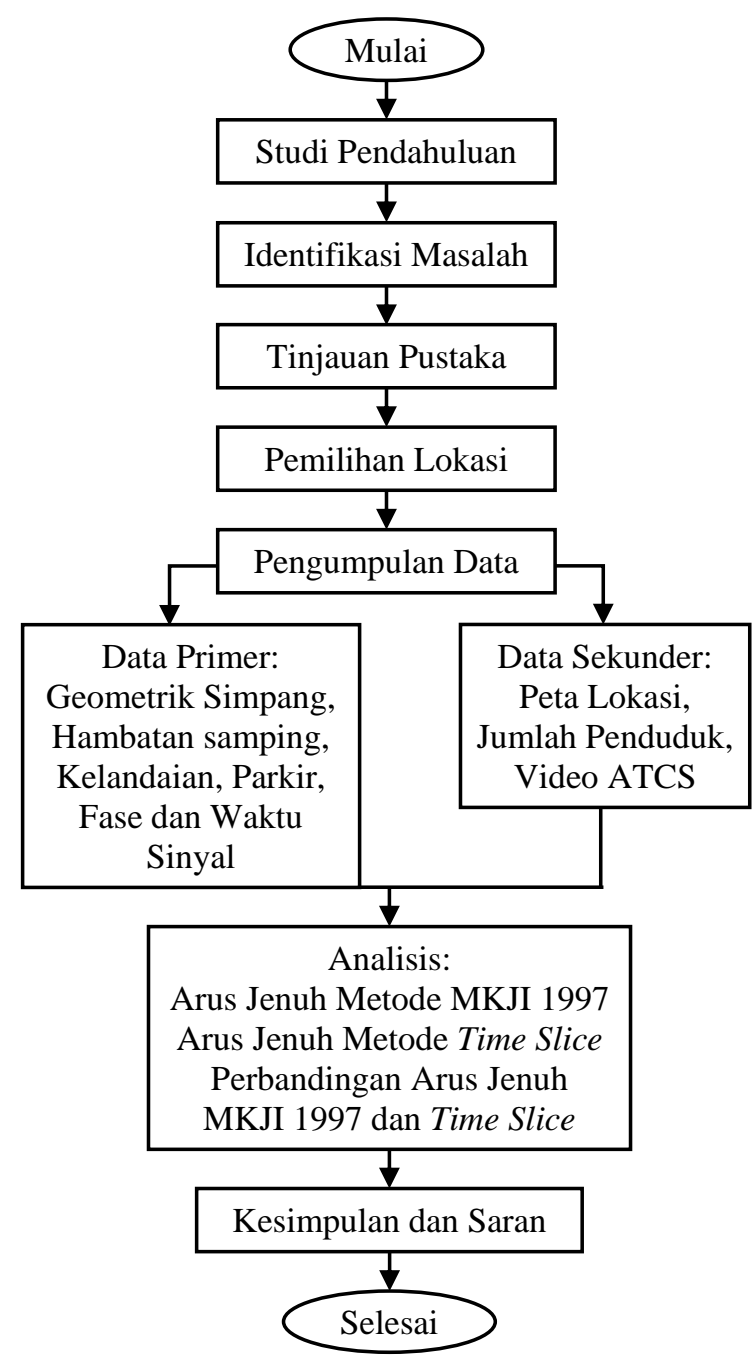

Gambar 5. Diagram alir penelitian
4 HASIL DAN PEMBAHASAN

\subsection{Data Geometrik Simpang}

Pengukuran geometrik simpang dilakukan di kedua simpang pada hari rabu tanggal 11 Maret 2020 mulai pukul 09.00 WITA dimana lebar efektif untuk pendekat barat (terlindung) di Simpang Subita adalah 6.4 meter, sedangkan lebar efektif untuk pendekat barat (terlawan) di Simpang Waribang adalah 4.1 meter.

\subsection{Data Penduduk}

Berdasarkan data Badan Pusat Statistik Provinsi Bali pada Tahun 2019 jumlah penduduk Kota Denpasar adalah 947.1 ribu jiwa.

\subsection{Data Hambatan Samping}

Berdasarkan survei di Simpang Subita dan Waribang diperoleh hasil untuk masing-masing pendekat barat termasuk dalam tipe lingkungan komersial dengan kelas hambatan samping rendah.

\subsection{Penentuan Jam Puncak}

Survei arus pergerakan dan volume lalu lintas dilakukan pada jam sibuk pagi, siang dan sore dimana satu jam dengan arus tertinggi digunakan untuk analisis arus jenuh. Penentuan jam puncak pada pendekat terlindung di Simpang Subita dan pendekat terlawan di Simpang Waribang dapat dilihat pada Gambar 6 dan 7. 


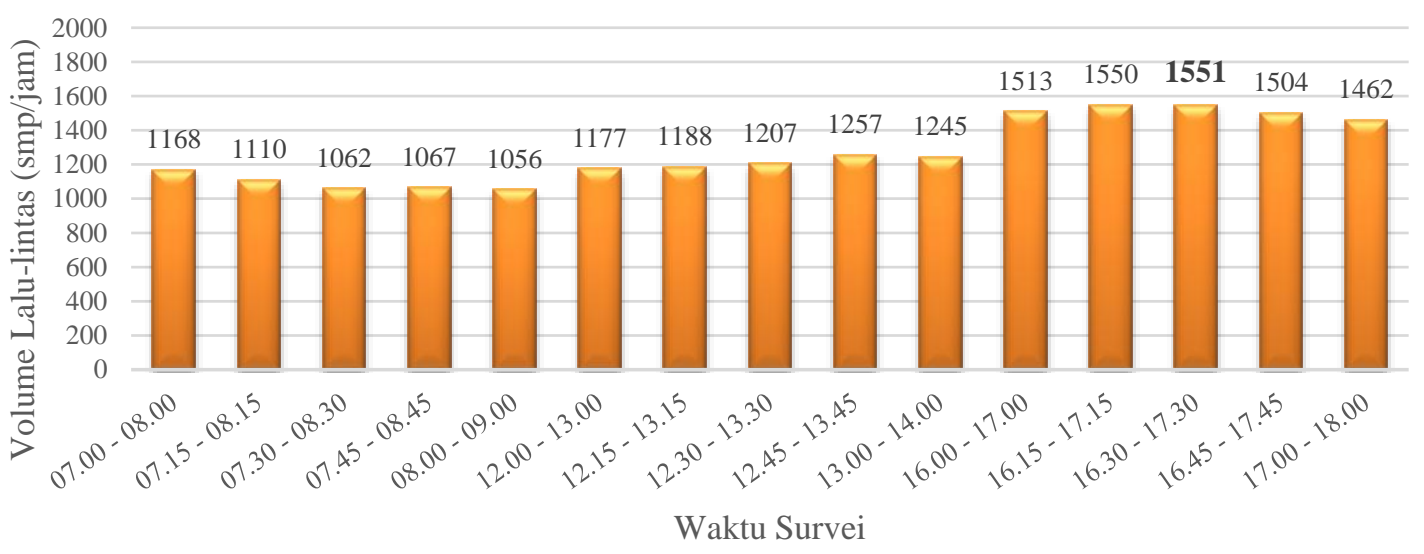

Gambar 6. Penentuan Jam Puncak di Simpang Subita

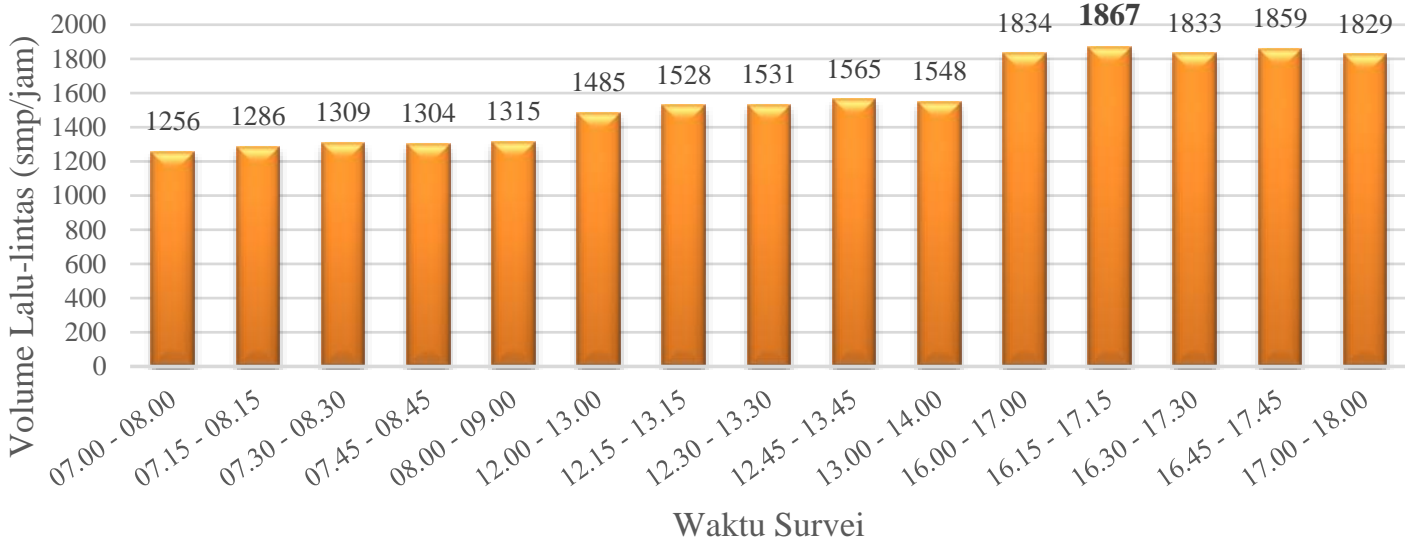

Gambar 7. Penentuan Jam Puncak di Simpang Waribang

Pada Gambar 6 dapat dilihat jam puncak untuk pendekat barat di Simpang Subita terjadi pada pukul 16.30-17.30 WITA dengan arus sebesar 1,551 smp/jam, sedangkan pada Gambar 7 dapat dilihat jam puncak untuk pendekat barat di Simpang Waribang terjadi pada pukul 16.15-17.15 WITA dengan arus sebesar $1,867 \mathrm{smp} / \mathrm{jam}$.

\subsection{Rasio Kendaraan}

Perhitungan rasio kendaraan dilakukan pada pendekat simpang yang ditinjau saat jam puncaknya dimana untuk rasio kendaraan bermotor (belok kiri $\left(\mathrm{P}_{\mathrm{LT}}\right)$ dan belok kanan (PRT)) diperoleh dari perbandingan antara arus pergerakan (belok kiri (QLT) atau belok kanan (QRT)) dengan total arus lalu-lintas (Qмv), sedangkan rasio kendaraan tidak bermotor ( $\left.\mathrm{P}_{\mathrm{UM}}\right)$ diperoleh dari perbandingan antara arus kendaraan tidak bermotor (QUM) dengan total arus kendaraan bermotor (QMv) seperti yang terlihat pada Tabel 2. 
Tabel 2. Rasio Kendaraan saat Jam Puncak

\begin{tabular}{ccc}
\hline & \multicolumn{2}{c}{ Pendekat } \\
& Terlindung & Terlawan \\
\hline $\mathrm{Q}_{\mathrm{LT}}(\mathrm{smp} / \mathrm{jam})$ & 23 & 82.8 \\
$\mathrm{Q}_{\mathrm{RT}}(\mathrm{smp} / \mathrm{jam})$ & 239.5 & 99.8 \\
$\mathrm{Q}_{\mathrm{MV}}(\mathrm{smp} / \mathrm{jam})$ & 1,001 & 1,867 \\
$\mathrm{Q}_{\mathrm{UM}}(\mathrm{kend} / \mathrm{jam})$ & 8 & 8 \\
$\mathrm{Q}_{\mathrm{MV}}(\mathrm{kend} / \mathrm{jam})$ & 3,195 & 3,824 \\
$\mathrm{P}_{\mathrm{LT}}$ & 0.023 & 0.044 \\
$\mathrm{P}_{\mathrm{RT}}$ & 0.239 & 0.053 \\
$\mathrm{P}_{\mathrm{UM}}$ & 0.003 & 0.002 \\
\hline
\end{tabular}

\subsection{Data Sinyal Lalu Lintas}

Data sinyal lalu-lintas saat jam puncak yang diperoleh pada pendekat barat di Simpang Subita meliputi waktu sinyal merah, kuning dan hijau dalam satu siklus secara berurutan adalah 72 detik, 3 detik dan 29 detik. Sedangkan waktu sinyal merah, kuning dan hijau dalam satu siklus secara berurutan pada pendekat barat di Simpang Waribang adalah 31 detik, 5 detik dan 43 detik. Fase lalu lintas di simpang subita dan waribang dapat dilihat pada Gambar 8 dan 9.

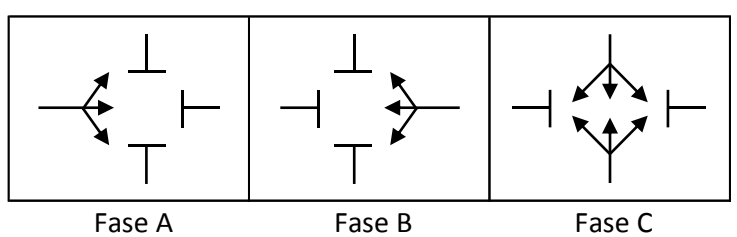

Gambar 8. Diagram Fase Lalu Lintas Simpang Subita

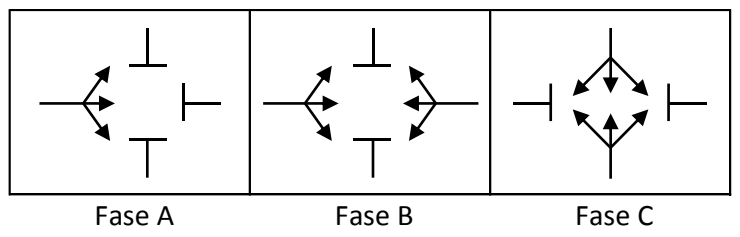

Gambar 9. Diagram Fase Lalu Lintas Simpang Waribang

\subsection{Analisis Arus Jenuh MKJI 1997}

Dengan menggunakan persamaan 3 diperoleh nilai arus jenuh (S) pada pendekat simpang yang ditinjau yaitu pendekat terlindung di Simpang Subita adalah 3,629 smp/jam dan pendekat terlawan di Simpang Waribang adalah 1,857 smp/jam seperti yang ditunjukkan pada Tabel 3.

Tabel 3. Analisis Arus Jenuh MKJI 1997

\begin{tabular}{ccc}
\hline & \multicolumn{2}{c}{ Pendekat } \\
& Terlindung & Terlawan \\
\hline $\mathrm{S}_{0} \quad(\mathrm{smp} / \mathrm{jam})$ & 3,840 & 2,080 \\
$\mathrm{~F}_{\mathrm{CS}}$ & 0.94 & 0.94 \\
$\mathrm{~F}_{\mathrm{SF}}$ & 0.95 & 0.95 \\
$\mathrm{~F}_{\mathrm{G}}$ & 1 & 1 \\
$\mathrm{~F}_{\mathrm{P}}$ & 1 & 1 \\
$\mathrm{~F}_{\mathrm{RT}}$ & 1.06 & - \\
$\mathrm{F}_{\mathrm{LT}}$ & 0.99 & - \\
$\mathrm{S}(\mathrm{smp} / \mathrm{jam})$ & 3,629 & 1,857 \\
\hline
\end{tabular}

\subsection{Analisis Arus Jenuh Time Slice}

Perhitungan arus jenuh dengan Metode Time Slice diawali dengan penentuan waktu irisan (slice) sebagai interval waktu pencatatan volume lalulintas pada pendekat yang ditinjau. Waktu irisan pada pendekat terlindung di Simpang Subita adalah 4 detik dimana periode hijaunya adalah 32 detik sehingga terdapat 8 bagian waktu irisan. Sedangkan waktu irisan pada pendekat terlawan di Simpang Waribang adalah 6 detik dimana periode hijaunya adalah 48 detik sehingga terdapat 8 bagian waktu irisan. Nilai arus jenuh tiap waktu irisan pada masing- 
masing pendekat dapat dilihat pada Tabel 4 dan 5.

Tabel 4. Arus Jenuh pada Pendekat Terlindung di Simpang Subita

\begin{tabular}{ccc}
\hline \multirow{2}{*}{ Irisan 4 detik } & \multicolumn{2}{c}{ Arus Jenuh } \\
& smp/4detik & smp/jam \\
\hline I (0-4 detik) & 3.5 & 2,123 \\
II (4-8 detik) & 4.2 & 2,511 \\
III (8-12 detik) & 4.0 & 2,374 \\
IV (12-16 detik) & 3.9 & 2,338 \\
V (16-20 detik) & 3.3 & 2,000 \\
VI (20-24 detik) & 3.1 & 1,851 \\
VII (24-28 detik) & 2.7 & 1,646 \\
VIII (28-32 detik) & 3.7 & 2,199 \\
\hline
\end{tabular}

$$
\begin{aligned}
\mathrm{S} & =\frac{\sum_{\mathrm{i}=1}^{\mathrm{n}} \mathrm{x}_{\mathrm{i}}}{\mathrm{n}} \\
& =\frac{2511+2374+2338+2000+1851+1646}{6} \\
& =2120
\end{aligned}
$$

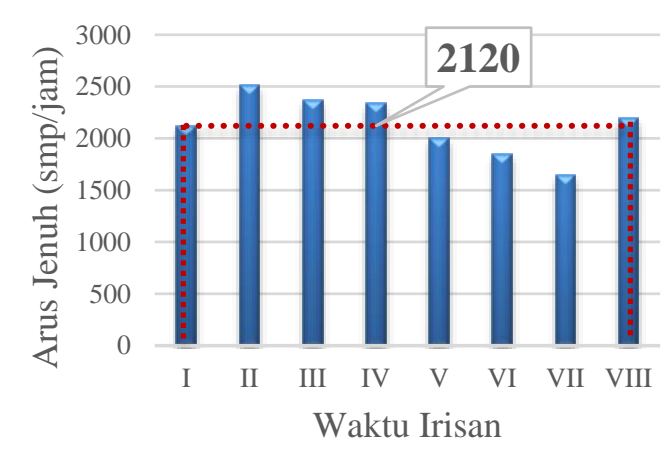

Gambar 10. Diagram Arus Jenuh Pendekat Terlindung di Simpang Subita

Tabel 5. Arus Jenuh pada Pendekat Terlawan di Simpang Waribang

\begin{tabular}{ccc}
\hline \multirow{2}{*}{ Irisan 6 detik } & \multicolumn{2}{c}{ Arus Jenuh } \\
& smp/6detik & smp/jam \\
\hline I (0-6 detik) & 6.3 & 3,796 \\
II (6-12 detik) & 5.8 & 3,469 \\
III (12-18 detik) & 5.1 & 3,081 \\
IV (18-24 detik) & 5.0 & 3,027 \\
V (24-30 detik) & 4.7 & 2,795 \\
VI (30-36 detik) & 4.6 & 2,785 \\
VII (36-42 detik) & 4.5 & 2,672 \\
VIII (42-48 detik) & 4.6 & 2,766 \\
\hline
\end{tabular}

$$
\begin{aligned}
S & =\frac{\sum_{\mathrm{i}=1}^{\mathrm{n}} \mathrm{x}_{\mathrm{i}}}{\mathrm{n}} \\
& =\frac{3469+3081+3027+2795+2785+2672}{6} \\
& =2971
\end{aligned}
$$

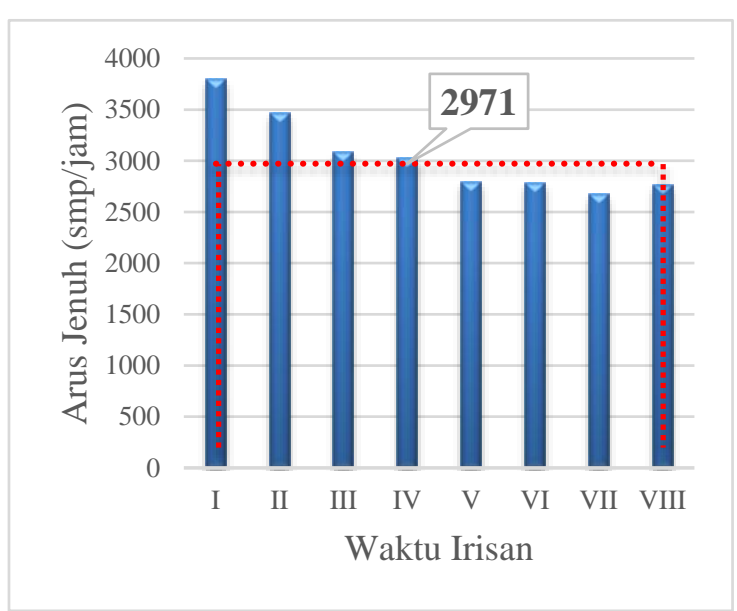

Gambar 11. Diagram Arus Jenuh Pendekat Terlawan di Simpang Waribang

Dari Gambar 10 dapat dilihat nilai arus jenuh pada pendekat terlindung di Simpang Subita adalah 2,120 smp/jam hijau, sedangkan dari Gambar 11 dapat dilihat nilai arus jenuh pada pendekat terlawan di Simpang Waribang adalah 2,971 smp/jam hijau.

\subsection{Perbandingan Arus Jenuh antara Metode MKJI 1997 dan Time Slice}

Perbandingan arus jenuh antara MKJI 1997 dengan Metode Time Slice pada pendekat terlindung di Simpang Subita dan pendekat terlawan di Simpang Waribang dapat dilihat pada Tabel 6. 
Tabel 6. Perbandingan Arus Jenuh

\begin{tabular}{cccc}
\hline \multirow{2}{*}{ Pendekat } & \multicolumn{3}{c}{ Arus Jenuh (smp/jam) } \\
& MKJI & Time Slice & $\%$ \\
\hline Terlindung & 3,629 & 2,120 & 71.18 \\
Terlawan & 1,857 & 2,971 & 37.49 \\
\hline
\end{tabular}

Berdasarkan data pada Tabel 6 dapat dilihat pada pendekat terlindung arus jenuh MKJI hasilnya lebih besar $71.18 \%$ dibandingkan arus jenuh Metode Time Slice sedangkan pada pendekat terlawan arus jenuh MKJI hasilnya lebih kecil $37.49 \%$ dibandingkan arus jenuh Metode Time Slice. Arus jenuh pada pendekat terlindung hasilnya berbanding terbalik dengan penelitian Kariyana et al. (2019) dimana arus jenuh MKJI nilainya lebih kecil dibandingkan Metode Time slice. Hal tersebut disebabkan pendekat yang ditinjau memiliki karakteristik lalu lintas yang berbeda yaitu memiliki lebar pendekat dan volume lalu lintas yang lebih besar. Pengukuran arus jenuh menggunakan MKJI diperoleh dari perkalian antara arus jenuh dasar dengan faktor penyesuaian yang ada dimana arus jenuh dasar ditentukan berdasarkan lebar pendekat efektif dikalikan 600, sedangkan pengukuran arus jenuh dengan Metode Time Slice merupakan arus jenuh nyata yang ada di lapangan yang tentunya lebih relevan digunakan dalam pengukuran arus jenuh.

\section{SIMPULAN DAN SARAN}

\subsection{Simpulan}

Berdasarkan hasil penelitian yang dilakukan pada pendekat terlindung di Simpang Subita dan pendekat terlawan di Simpang Waribang diperoleh hasil sebagai berikut:

1. Arus jenuh pada pendekat terlindung di Simpang Subita berdasarkan MKJI 1997 adalah 3,629 smp/jam hijau lebih besar $41.58 \%$ dibandingkan dengan Metode Time Slice yaitu 2,120 smp/jam hijau, sedangkan hasil arus jenuh pada pendekat terlawan di Simpang Waribang berdasarkan Metode Time Slice adalah 2,971 smp/jam hijau lebih besar $\quad 37.49 \%$ dibandingkan dengan MKJI 1997 yaitu 1,857 smp/jam hijau.

2. Dari hasil penelitian terdahulu dan penelitian lainnya pada simpang bersinyal diperoleh nilai arus jenuh yang berbedabeda jika perhitungannya menggunakan Metode Time Slice. Hal ini disebabkan karena Metode Time Slice menghasilkan arus jenuh nyata yang ada di lapangan. 


\subsection{Saran}

Adapun saran yang bisa diberikan berdasarkan kesimpulan pada penelitian ini adalah:

1. Perlu dilakukan penelitian serupa pada lokasi yang memiliki karakteristik lalu-lintas yang sama meliputi geometrik, proporsi kendaraan dan tipe pendekat untuk menentukan metode yang relevan dalam penentuan arus jenuh.

2. Dalam perhitungan kinerja simpang bersinyal hendaknya menggunakan Metode Time Slice dalam penentuan arus jenuh sehingga diperoleh hasil kinerja yang sesuai dengan kondisi nyata di lapangan.

\section{DAFTAR PUSTAKA}

Anonim. (1997). Manual Kapasitas Jalan Indonesia (MKJI). Jakarta: Direkctorat Jenderal Bina Marga.

Anonim. (2014). Pedoman Kapasitas Jalan Indonesia (PKJI). Jakarta: Kementerian Pekerjaan Umum.

Anonim. (2020). Provinsi Bali Dalam Angka 2020. Denpasar: Badan Pusat Statistik Provinsi Bali.

Balaka, R., \& Yudistira, W. (2018). Analisa Model Arus Jenuh Pada Simpang Bersinyal (Studi Kasus : Jl. Drs. H. Abdullah Silondae - Jl. Syech Yusuf - Jl. Lawata). Jurnal Stabilita, 6(3), 49-54.
Bowoputro, H., Arifin, M. Z., Djakfar, L., \& Kusumaningrum, R. (2014). Kajian Arus Jenuh Pada Simpang Bersinyal di Kota Malang Bagian Selatan. Jurnal Rekayasa Sipil, 8(2), 152-157.

Fadli, S., \& Elkhasnet. (2012). Perbandingan Nilai Arus Jenuh pada Pendekat Simpang Dengan dan Tanpa Ruang Henti Khusus. Jurnal Transportasi, 12(3), 217-226.

Kariyana, I M., Ardana, P. D. H., \& Sumarda, G. (2019). Analisis Arus Jenuh di Simpang Bersinyal dengan Metode Time Slice dan MKJI 1997 (Studi Kasus Simpang Sudirman Yos Sudarso). Prosiding Seminar Nasional Peningkatan Mutu Perguruan Tinggi, 257-264. Tanjung Benoa-Bali: Universitas Mercu Buana Jakarta.

Lubis, M. (2017). Analisa Nilai Ruang Henti Khusus (RHK) Kendaraan Roda Dua di Persimpangan Jl. Imam Bonjol - Jl. Perdana Kota Medan. Buletin Utama Teknik, 13(1), 61-68.

Lubis, R. I., \& Surbakti, M. S. (2017). Analisa Arus Jenuh Dan Panjang Antrian Pada Simpang Bersinyal Dan Mikrosimulasi Menggunakan Software Vissim (Studi Kasus: Simpang Hotel Danau Toba Internasional dan Simpang Karya Wisata di Kota Medan). Jurnal Teknik Sipil USU, 6(1).

Negara, N. W., Kwintaryana, P., \& Wibawa, I G. A. S. B. (2019). Perbandingan Nilai Saturation Flow antara Metode Time Slice dengan Pendekatan DPU 1997. (Studi Kasus: Persimpangan Jalan Kebo Iwa Dengan Jalan Arteri Gatot Subroto Barat). Jurnal Spektran, 7(2), 271-279.

Nguyen, H. D. (2016). Saturation Flow Rate Analysis at Signalized 
Intersections for Mixed Traffic Conditions in Motorcycle Dependent Cities. Transportation Research Procedia, 15, 694-708.

Nguyen, H., \& Montgomery, F. (2007). Different Models of Saturation Flow in Traffic Dominated by Motorcycles. Journal of the Eastern Asia Society for Transportation Studies, 7, 2381-2395.

Panjaitan, T. U. Y., Amirotul, M. H. M., \& Legowo, S. J. (2018). Studi Variasi Keberangkatan Lalu Lintas Dan Perbandingan Arus Jenuh Metode Time Slice Dengan Arus Jenuh MKJI 1997 Pada Simpang Bersinyal Dengan Short Time Countdown Timer. E-Jurnal Matriks Teknik Sipil, 592-601.

Subandi, A., \& Gunawan, M. G. (2017). Ekivalen Mobil Penumpang Kendaraan Berat Dan Motor Belok Kanan Pada Simpang Bersinyal. Jurnal Mesa Fakultas Teknik Universitas Subang, 1-8.

Susilo, B. H., \& Solihin, Y. (2011). Modification of Saturation Flow Formula by Width of Road Approach. Procedia Social and Behavioral Sciences, 16, 620-629.

Tamin, O. Z. (2000). Perencanaan dan Pemodelan Transportasi. Bandung: ITB.

Transportation Research Board. (2000). Highway Capacity Manual. Washington, D.C.: Transportation Research Board Publications. 